\title{
Impacts of agricultural land use on biological integrity: a causal analysis
}

\author{
C. M. Riseng, ${ }^{1,3}$ M. J. Wiley, ${ }^{1}$ R. W. Black, ${ }^{2}$ and M. D. Munn $^{2}$ \\ ${ }^{1}$ University of Michigan, School of Natural Resources and Environment, 440 Church Street, Ann Arbor, Michigan $48109-1041$ USA \\ ${ }^{2}$ U.S. Geological Survey, Washington Water Science Center, 934 Broadway, Suite 300, Tacoma, Washington 98402 USA
}

\begin{abstract}
Agricultural land use has often been linked to nutrient enrichment, habitat degradation, hydrologic alteration, and loss of biotic integrity in streams. The U.S. Geological Survey's National Water Quality Assessment Program sampled 226 stream sites located in eight agriculture-dominated study units across the United States to investigate the geographic variability and causes of agricultural impacts on stream biotic integrity. In this analysis we used structural equation modeling (SEM) to develop a national and set of regional causal models linking agricultural land use to measured instream conditions. We then examined the direct, indirect, and total effects of agriculture on biotic integrity as it acted through multiple water quality and habitat pathways. In our nation-wide model, cropland affected benthic communities by both altering structural habitats and by imposing water quality-related stresses. Regionspecific modeling demonstrated that geographic context altered the relative importance of causal pathways through which agricultural activities affected stream biotic integrity. Cropland had strong negative total effects on the invertebrate community in the national, Midwest, and Western models, but a very weak effect in the Eastern Coastal Plain model. In the Western Arid and Eastern Coastal Plain study regions, cropland impacts were transmitted primarily through dissolved water quality contaminants, but in the Midwestern region, they were transmitted primarily through particulate components of water quality. Habitat effects were important in the Western Arid model, but negligible in the Midwest and Eastern Coastal Plain models. The relative effects of riparian forested wetlands also varied regionally, having positive effects on biotic integrity in the Eastern Coastal Plain and Western Arid region models, but no statistically significant effect in the Midwest. These differences in response to cropland and riparian cover suggest that best management practices and planning for the mitigation of agricultural land use impacts on stream ecosystems should be regionally focused.
\end{abstract}

Key words: agriculture; causal analysis; invertebrate community; land use; structural equation modeling; water quality.

\section{INTRODUCTION}

Agricultural land use has been often identified as a primary source of excess nutrients, widespread sedimentation, and toxic and organic pollution in rivers around the world (Osborne and Wiley 1988, Johnson et al. 2003, Dodds and Oakes 2006, Scanlon et al. 2007). Globally, population growth and the attendant increase in agricultural fertilizers has been predicted to increase nutrient loadings to rivers by $145 \%$ in 2050 (Malmqvist and Rundle 2002). In the United States, federal environmental agencies have reported that nutrient enrichment is a problem in $40 \%$ of the nations' streams and rivers (USGS 1999, U.S. EPA 2004). This is not a surprising association since the use of nitrogenous fertilizers and pesticides has increased in the United States 20-fold since 1945 (Puckett 2004, Gilliom et al. 2006, Mueller and Spahr 2006). Destruction of natural

Manuscript received 14 January 2011; revised 22 April 2011; accepted 25 April 2011. Corresponding Editor: C. Nilsson.

${ }^{3}$ E-mail: criseng@umich.edu riparian land cover, especially wetlands, can further exacerbate nutrient loading from agricultural lands by reducing or eliminating riparian nutrient uptake, denitrification, and sedimentation of adsorbed phosphorus (Verhoeven et al. 2006).

Agriculture-related nutrient exports have been linked to serious ecological impacts in receiving waters (marine and freshwater), including eutrophication and its more noxious symptoms: hazardous algal blooms and hypoxia (Alexander et al. 2000, Rabalais et al. 2002). Likewise, agricultural land use has often been implicated in the widespread loss of biological integrity observed in many continental river systems; significant negative correlations often being reported between measures of stream biological integrity and various measures of upstream agriculture (Whiles et al. 2000, Munn et al. 2002, Wiley et al. 2002, Heatherly et al. 2007, Wang et al. 2008, Riseng et al. 2010). As a result of these implied impacts on biological integrity, the control of agricultural nutrient exports and the implementation of agricultural best management practices (BMPs) have become a common focus of watershed management programs 
across the United States (Frissell and Bayles 1996, U.S. EPA 2000, Sharpley et al. 2008, Steiner et al. 2008).

Ecological mechanisms linking nutrient loading to eutrophication, anoxia, and related phenomena in stratified receiving water bodies are well understood (Diaz 2001, Smith 2002). However, the same cannot be said for the linkage between agriculture and biological integrity of upland streams and rivers. Although correlations between agricultural land use and lower trophic-level biological integrity are often observed, exceptions frequently occur (e.g., Snyder et al. 2003, King et al. 2005) and the correlations themselves are often much weaker than those observed with urban land cover (Wiley et al. 2002, Riseng et al. 2006). Furthermore, the causal mechanisms that potentially link agricultural land use to river ecosystem condition are complex and poorly understood, involving processes operating at multiple scales (Munn et al. 2009) and via multiple pathways. To better understand how current agricultural practices affect local biological integrity and to improve those practices, there is a need to identify and evaluate the specific direct and indirect causal paths that link agricultural land use to the observed responses of riverine communities.

Biological assessments detect the cumulative impact of multiple ecological stressors on biological communities (Hilsenhoff 1988, Karr and Chu 1999, Davis et al. 2003). These presumably include the physiological effects of temperature and water chemistry, the ecological and behavioral effects of local hydraulics and physical habitat (sediment and substrate), and modifications in biological interactions among populations (predation, competition, and disease). Since most of these proximate factors have strong interactions with each other, the resulting causal system is necessarily complex and full of both indirect interactions and spurious (noncausal) correlations (Pugesek and Grace 1998, Grace 2003, Riseng et al. 2004, Baker and Wiley 2009). Regional covariates including biogeographic constraints, climate, and underlying geology shape distributions of many of the relevant proximate variables and therefore must also influence the way in which local agricultural practices impact local streams (Riseng et al. 2004, Waite et al. 2004, Seelbach and Wiley 2005, Stevenson et al. 2006). For example, the effect of agriculture on river hydrology depends on both regional climate and physiography. In arid regions, consumptive water use by agriculture may be a dominant pathway of impact on surface and groundwater systems, while in more humid climates, land drainage may be the principal way in which agriculture modifies river hydrology (Falkenmark and Rockström 2006).

To evaluate potential causal pathways while accounting for geographic differences in physiography and hydrology, we employed structural equation modeling (SEM; Bollen 1989, Shipley 2000) in an analysis of a regionally nested national data set. SEM parameterizes and evaluates explicit structural hypotheses about cause-effect relationships within a set of observed and latent variables. The structural hypothesis is specified a priori based on knowledge of system mechanisms and structure. The model is represented as a set of linear equations, and is parameterized by finding a simultaneous solution minimizing the difference between the model-implied and the observed covariance (sample data) matrices. Solutions provide estimates of direct, indirect, and total (sum of direct and indirect effects) effects that causally link the variables in the model (Bollen 1989, Tomer and Pugesek 2003). Comparison of nested models provides the ability to compare the relative strength of pathways between models and, for our purposes, to examine how regional variation in natural landscape conditions might influence how agriculture affects stream ecosystems.

The goal of this study was to explore the complex system of causes and effects by which agricultural land use interacts with the biological integrity of stream ecosystems. For this analysis, we used the USGS's National Water Quality Assessment Program (NAWQA; Munn et al. 2002) regionally nested national data set of agricultural watersheds to develop a set of national and regional SEM models. We began by developing a national model, and then partitioned the data set by region to explore how geographic variability affected model parameterization and our interpretations.

\section{Methods \\ Study units}

Data were gathered by the U.S. Geological Survey's (USGS) National Water Quality Assessment Program (NAWQA). This study was conducted in eight study units characterized by extensive agricultural land use and located throughout the United States (Fig. 1; Appendix A). For analysis, we aggregated the study unit data sets into (1) a single national data set, and (2) into three regional data sets based on unit proximity and similarities in climate and physiography (Cushing and Allan 2001). The Columbia plateau (CCYK) and the Upper Snake River study units (USNK) are arid to xeric and were grouped as a Western Arid regional data set (WA); all sites were located in the western United States and within the Columbia River basin. Agriculture is heavily dependent on irrigation, while forests and wetlands are relatively rare. The Upper Mississippi (UMIS), Central Nebraska (CNBR), White Miami (WHMI), and the Ozark Plateau (OZRK) study units are located in the semi-humid plains and were grouped in a Midwest (MW) regional data set; all sites were located in the central United States and drain to the Mississippi River. Wetlands were more abundant in the Midwest than Western Arid region. The Georgia Coastal Plain (GCP) and the Delmarva Peninsula (DLMV) study units were grouped in an eastern seaboard Coastal Plain (CP) regional data set with sites located in the eastern United States along the coast and draining to the Atlantic Ocean. Coastal Plain streams 


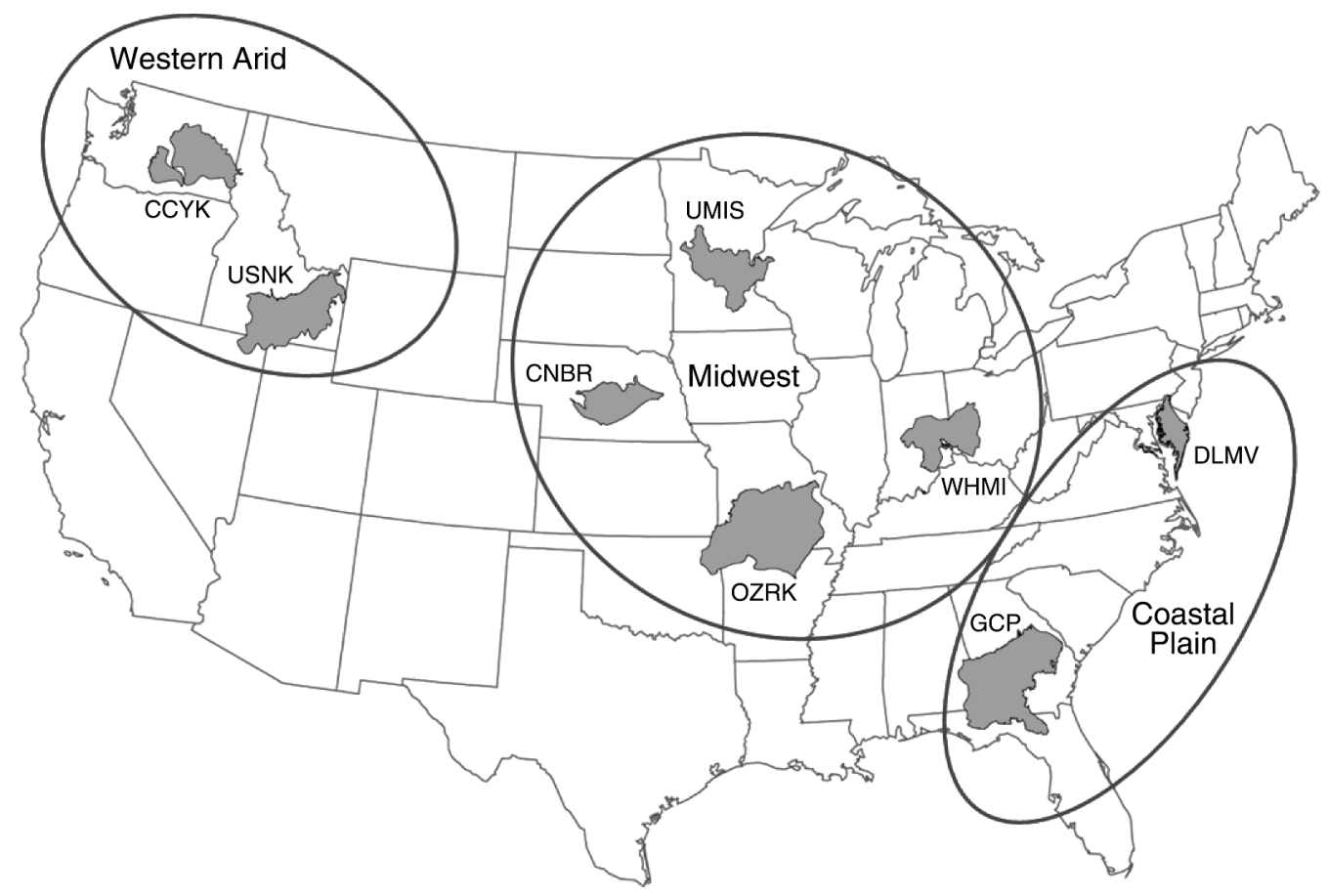

FIG. 1. Study unit location map illustrating regional groups: Western Arid, including the Columbia Plateau (CCYK, $n=29$ [sites sampled per study unit]) and Upper Snake (USNK, $n=29)$; the Midwest, including Central Nebraska $(\mathrm{CNBR}, n=27)$, Ozark (OZRK, $n=30$ ), Upper Mississippi (UMIS, $n=29$ ), and White Miami (WHMI, $n=29$ ); and the Coastal Plain, including the Georgia Coastal Plain (GCP, $n=29$ ) and Delmarva Peninsula (DLMV, $n=25$ ).

typically had wide riparian zones with forested floodplains and abundant canopy cover. Analyses were conducted at both the national (across all eight units) and three regional scales.

\section{Site selection}

In each study unit, sites were selected to represent a nutrient concentration gradient ranging from "little impacted" to "highly impacted" by agricultural land use. The initial selection of sites relied partially on modeled estimates of nitrogen and phosphorus loading to each of the independent basins derived from countylevel fertilizer sales, atmospheric deposition, and livestock data (Ruddy et al. 2006). National-scale analysis of the NAWQA data has demonstrated that nitrogen loading to the land surface was significantly related to nitrogen yields to streams (Fuhrer et al. 1999) and could be used as a surrogate for nutrient concentration in streams with sparse water quality data. Final selection of sites was based upon modeled nutrient loading to a basin, existing USGS nutrient data, and similarity of stream habitat with other sites within the study unit. This approach yielded $28-30$ wadeable sites within each study unit that spanned the greatest range in nutrient concentrations possible, given similar stream habitats within a study unit. The sites were sampled between 2003 and 2007 (Appendix A).

\section{Catchment and riparian attributes}

Basinwide (upstream catchment) and riparian measures of land cover, soil characteristics, topographic features, and runoff estimates were developed for each site using ArcInfo Workstation (ESRI 1997), a commercially available geographic information system (GIS). All raster processing took place at $30 \mathrm{-m}$ resolution. The source for land cover information (Anderson Level 1; Andersen et al. 2001) was an enhanced version of the USGS National Land Cover Data 2001 (Vogelmann et al. 2001). The 1:100 000-scale National Hydrography Dataset (Simley and Carswell 2009) was the source for the streams data. Watershed boundaries for all potential study sites within a study unit were derived from 30-m digital elevation model (DEM) data obtained from the USGS Elevation Derivatives for National Applications project. Riparian variables were determined from the GIS land cover at the reach scale $250 \mathrm{~m}$ from the stream centerline using methods outlined in Johnson and Zelt (2005). A base flow index (BFI), the component of streamflow that can be attributed to groundwater discharge into streams, was estimated for watersheds from the national $1-\mathrm{km}$ resolution data set developed by Wolock (2003). While not expected to precisely quantify base flow, it has been found to be a useful indicator of base flow variation. 


\section{Physical habitat and water chemistry}

Physical habitat and stream flow were assessed in each sampled stream reach defined as the repetition of a single geomorphic sequence (i.e., riffle-pool-riffle-pool), or alternately, as 20 channel widths using standard NAWQA field methods (Fitzpatrick et al. 1998). Wetted channel width $(\mathrm{m})$, water depth $(\mathrm{cm})$, water velocity $(\mathrm{cm} / \mathrm{s})$, percentage substrate type (bedrock, boulder, cobble, gravel, sand, and silt), and percentage of woody debris were measured along transects; gradient and geomorphic features were characterized for the entire reach. Substrate type data were size classed using a modified Wentworth scale (Cummins 1962), and cumulative frequency plots were used to calculate the diameter of the 84th percentile particle $\left(D_{84}\right)$ as an estimate of relative channel roughness. Channel shear stress was calculated as the product of water surface gradient, channel hydraulic radius, gravity, and the density of water (Gordon et al. 1995). All habitat characterizations were performed during macroinvertebrate sampling at stable low-flow conditions.

Nutrient samples were collected twice at each site using a depth- and width-integrated sampling method (Shelton 1994); the first sample was collected 30 days prior to the macroinvertebrate and reach-scale habitat sampling, and the second was collected concurrent with the macroinvertebrate and habitat sampling. Suspended sediment samples were collected during the second sampling. Final nutrient concentrations were calculated as the average for the two sampling periods. Samples collected for analyses of dissolved constituents were filtered in the field $(0.45 \mu \mathrm{m})$; samples for analysis of total phosphorus and suspended sediments were unfiltered. Samples were analyzed for a full suite of nutrients using standard colorimetric methods (Fishman 1993, Patton and Kryskalla 2003), but only dissolved inorganic nitrogen (DIN) and total phosphorus (TP) were used in this analysis to represent nutrient input to streams. Dissolved inorganic nitrogen (DIN) was calculated by summing the concentrations of $\mathrm{NO}_{3}$, $\mathrm{NO}_{2}$, and $\mathrm{NH}_{4}$. Water temperature $\left({ }^{\circ} \mathrm{C}\right)$, alkalinity, and conductivity were also measured. Since conductivity varies naturally with local geology and resulting alkalinity, "excess" conductivity, the conductivity beyond that due to alkalinity components (i.e., in excess), was calculated as: excess conductivity $=0.00316 \times$ alkalinity (as $\left.\mathrm{CaCO}_{3}\right)^{(0.88401)}$ based on standardized laboratory $\mathrm{CaCO}_{3}$ solution $\left(R^{2}=0.991\right)$.

\section{Macroinvertebrate community}

Macroinvertebrate samples were collected from coarse substrate during the summers of 2003-2007. Coarse substrate was defined as either gravel or cobble typical of riffles or large woody debris where sand substrates dominated. A detailed discussion of macroinvertebrate sampling protocol can be found in Moulton et al. (2002). Five composited macroinvertebrate samples collected with a $500-\mu \mathrm{m}$ net were identified to the lowest taxonomic level possible, typically the genus level. For each site, a minimum of 300 organisms were counted and identified.

Over 150 invertebrate community metrics were calculated using the USGS developed program Invertebrate Data Analysis System (IDAS; Cuffney 2003). The metrics described abundance and richness of the invertebrate community composition, dominance, functional feeding group, behavior, and tolerance. Ecological tolerance values indicate how well each taxon is expected to tolerate pollution and were obtained from the U.S. EPA (Barbour et al. 1999, Cuffney 2003). Tolerance values ranged from 1 to 10 , where low values indicate an intolerant taxa (1-4) and high numbers indicate a tolerant taxa (7-10). We calculated average tolerance values using both national and region-specific tolerance estimates; national tolerances were an average of all of the regional tolerances (see Cuffney 2003).

\section{Data analysis}

Environmental data for each site were summarized in MS Access at local (physical habitat, water chemistry concentration, flow, and flow indices), stream riparian buffer (land use, geology), watershed (land use, geology), and regional (ecoregion) scales. Preliminary descriptive statistics, correlation analyses, multiple linear regression (MLR), and ANOVAs, were performed using Data Desk 6.1 software (Velleman 1997). Structural equation modeling (SEM) of the influence of agricultural settings on stream ecosystems was implemented using AMOS 17 software (Arbuckle and Wothke 1999, SPSS 2009).

\section{SEM model development}

Following initial exploratory analyses, development of a SEM typically follows three key steps and our analysis was, in this sense, typical. First we developed a conceptual causal model; a construct that represents the hypothesized causal linkages between variables in the system being analyzed. From that conceptual model, we then developed a generalized structural model (in the form of a specific causal path hypothesis) constrained by the availability of variables in the NAWQA data set. The third step was to fit the structural model to the sample data to produce a fitted, parameterized structural model. The fitted model provides estimates of the magnitude of the hypothesized causal relationships between variables from which statistics that describe how well the model structure fits the observed data structure are calculated. These phases are described in more detail in the following paragraphs.

We developed the conceptual model linking agricultural cropland indirectly to stream biological integrity (Fig. 2a) based on the large existing literature (e.g., Richards et al. 1996, Allan and Johnson 1997, Meador and Goldstein 2003) and basic ecological principles. We expected land use to act only indirectly on biological integrity via effects on proximal variables like substrate, water quality, 
a) Conceptual causal model

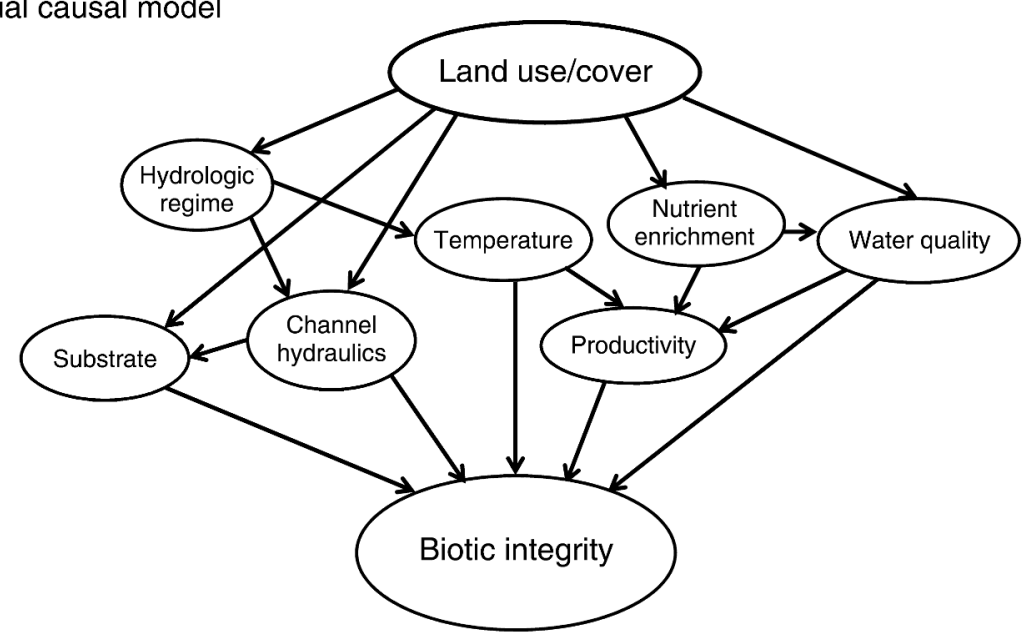

b) General structural model

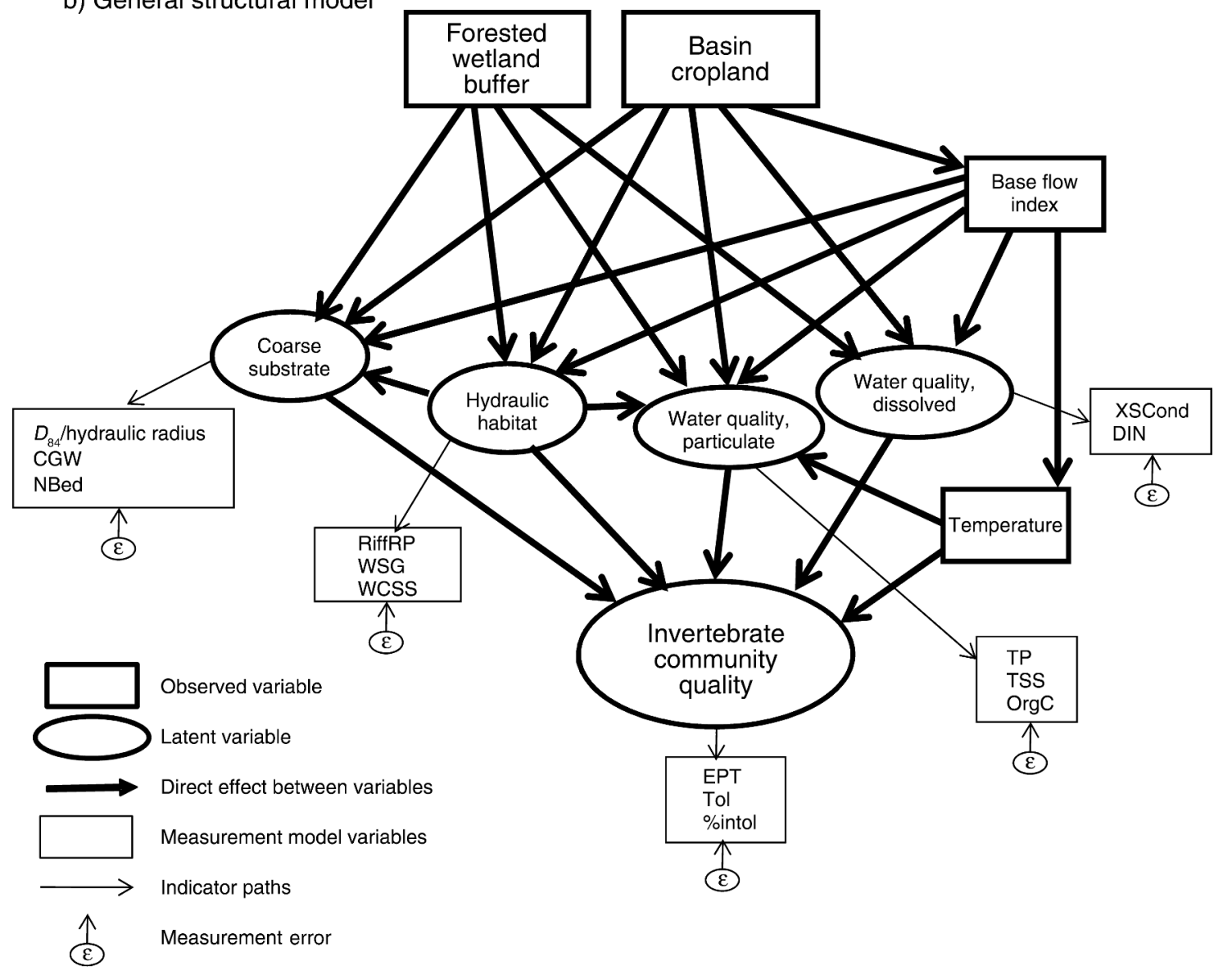

FIG. 2. Conceptual construct identifying the expected direct and indirect pathways for land use/cover to affect invertebrate stream communities: (a) conceptual causal model developed from theory and (b) general structural model and measurement model components based on available data. See Table 2 for abbreviations.

nutrient enrichment, productivity, channel hydraulics, hydrologic regimes, and temperature. Biological integrity was selected as the key response variable reflecting both national policy and common practice.
Based on data availability and exploratory analyses, our general structural model (Fig. 2b) included two exogenous driving variables (basin cropland and riparian forested wetlands), five unmeasured concept vari- 
ables (latent variables) and their associated measurement models, and 16 endogenous variables (e.g., base flow index, total phosphorus). In the general model, agricultural land use was represented by the percentage of the catchment area used for the production of annual crops, such as corn, soybeans, vegetables, tobacco, and cotton, and perennial woody crops such as orchards and vineyards, as well as pasture and fallow fields (called basin cropland throughout). Riparian forested wetlands was a second exogenous land use/cover variable that represented natural land cover that might ameliorate the effects of basin cropland and independently influence stream invertebrate communities. Riparian forested wetland cover was the proportion of the riparian zone dominated by forest or shrub land vegetation and where the soil or substrate is periodically saturated with or covered with water.

In our SEM, the measurement model structure provided an estimate of each latent conceptual variable (Fig. 2b; Bollen 1989). Two of the measurement models (coarse substrate availability and hydraulic habitat) were expected to have positive or mitigating effects on the invertebrate community. Two other water quality conceptual variables (reflecting dissolved and particulate loads) were expected to have potentially negative impacts. The final measurement model was the key response variable of biological integrity as reflected in the three invertebrate community metrics. Measurement models utilize multiple correlated measures to derive an estimate of the underlying theoretical concept (unmeasureable latent variable). In this framework, the latent variable is represented by the common (shared) variance of the multiple indicator variables that are thought to play similar and complementary ecological roles (Grace 2003).

The coarse substrate (CSub) measurement model indicators included percentage of cobble, gravel, and wood, the 84th percentile particle divided by the hydraulic radius at low flow, and the proportion of the stream reach that was not embedded. Hydraulic habitat $(\mathrm{HydH})$ indicators included the relative percentage of riffle habitat (percentage of riffle/[percentage of pool + percentage of run]), the water surface gradient, and the water channel shear stress at low flow. The stressor concept of dissolved water quality (WQ-d) was represented by excess conductivity (see Methods: Physical habitat and water chemistry) and dissolved inorganic nitrogen (DIN); the sum of nitrate, nitrite, and ammonium concentrations, although nitrate was the predominant component ( $87 \%$ on average). Nitrogen fertilizers are commonly rapidly oxidized and exported as highly soluble nitrate, which, at high concentrations, is also frequently correlated with residual pesticides and other agricultural contaminants; thus representing a broad aspect of dissolved water quality as potentially affected by agriculture. The concept of particulate water quality (WQ-p) represented the potential impacts of organic loading and the associated decomposition on dissolved oxygen minima and was indicated by three factors: mean concentrations of total phosphorus, total suspended sediments, and total suspended organic carbon.

Biological response to agriculture was represented by the invertebrate community quality (ICQ) conceptual variable. This measurement model included three indicators of invertebrate community sensitivity to environmental degradation: percentage of intolerant individuals (tolerances $<4$ on a $0-10$ scale), mean tolerance for individuals in the invertebrate sample (inverted tolerances so that high numbers indicated high average tolerance), and number of Ephemeroptera, Plecoptera, and Trichoptera (EPT) taxa, a common taxonomic indicator of community "health." In our analysis, we selected these three common metrics of invertebrate community condition from the larger set $(n$ $\approx 150$ ) of invertebrate community metrics (Hilsenhoff 1988, Maxted et al. 2000, Cuffney 2003) based on an initial evaluation using correlation and principal component analysis, and subsequently based on fit to the overall model. Wang et al. (2007) examined a suite of invertebrate metrics in Midwest streams and found similar metrics (EPT richness, community tolerance) most strongly correlated to nutrients and other physiochemical factors.

The parameters for the national model were estimated by fitting the general model to the national data set and iteratively refining the base model linkages guided by modification index statistics (Hershberger et al. 2003) to identify the best fitting causal structure consistent with known biological and physical relationships (i.e., nonsensical modifications were not considered). Fit was evaluated using multiple metrics, including: (1) $\chi^{2}$ statistic, a measure of correspondence between observed and implied covariance matrices; (2) root mean square error approximation (RMSEA), an estimator of data fit to the causal hypothesis; and (3) the Comparative Fit Index (CFI), an index robust to small sample size and non-normal data distributions, should they occur (Tomer and Pugesek 2003). Statistical significance of effect coefficients was estimated using the bootstrap option in AMOS. Most variables were transformed $(\ln (x$ $+1)$ ) to conform to normality assumptions. Normality assessment within AMOS indicated that most variables were within expected skewness $(<2.0)$ and kurtosis $(<7.0)$ normality constraints; a few variables exceed normality assumptions; therefore, we included the CFI fit index to assess model fit given minor non-normal distributions (Tomer and Pugesek 2003). The CNBR study unit streams had sites with extremely high levels of total phosphorus (range $0.14-1.71 \mathrm{mg} / \mathrm{L}$ ) that resulted in skewed distributions across data for combined study units. Therefore, we set $0.5 \mathrm{mg} / \mathrm{L}$ as the upper limit on TP values and set all values above this threshold to 0.5 $\mathrm{mg} / \mathrm{L}$, which resulted in a more normal distributions for TP (ln-transformed in the models). TP values $>$ $0.5 \mathrm{mg} / \mathrm{L}$ are far above saturation levels for periphyton 
and likely to be unusable excess in both streams and lakes (Alexander and Smith 2006, Stevenson et al. 2006)

After we refined and tested the fit of the national model structure, we fit the national model to each regional data set independently to explore geographic variability in the structural and causal relationships between agricultural land use and stream biotic integrity. We again iteratively adjusted model linkages and the measurement model components for each regional model to reflect the best available regional indicators and to maximize goodness of fit.

\section{Results}

Agricultural land cover varied within and between regional study units. Mean proportion of agricultural land use for site basins across the eight study units was $46 \%$ and ranged from $20 \%$ to $83 \%$; mean proportion cropland was $33 \%$ and ranged from $0.5 \%$ to $76 \%$ (Appendix B). The range of basin agricultural land cover across all study sites was from $0 \%$ to $93 \%$ and cropland from $0 \%$ to $91 \%$. Mean agriculture and cropland were significantly higher in the WHMI study unit sites in southern Indiana, where agriculture ranged from a minimum of $67 \%$ to a maximum of $93 \%$, and cropland from $34 \%$ to $91 \%$. Mean agriculture was significantly lower in the USNK, GCP, and CCYK study units $(20 \%, 32 \%$, and $36 \%$, respectively) and mean cropland was significantly lower in the OZRK and USNK study unit sites ( $0.5 \%$ and $15 \%$, respectively). There was also variability in natural riparian land cover between study units, represented in our analysis by riparian forested wetlands, which were generally higher in the Coastal Plain region study sites of the GCP and somewhat less so in the DLMV (Appendix B).

Physical habitat varied among regions with the western United States study units having higher basin elevations, water surface slopes, channel shear stress, and relative percentage of riffle habitat in general. As might be expected, in higher elevation watersheds (CCYK, USNK, and OZRK study units), the proportion of cobble and coarse gravel substrate was highest, while the two coastal plain and one Midwestern study unit (UMIS) had substantially higher proportions of woody debris substrate. The GCP, CNBR, and UMIS study streams were highly embedded on average. These differences in physical habitat between study units commonly split along regional lines, although not entirely.

Total phosphorus, total suspended sediments, and suspended organic carbon were all significantly higher in the Midwestern CNBR study unit (one-way ANOVA, Tukey's contrasts, $P<0.05$ ), while conductivity and excess conductivity were substantially higher in the USNK, CNBR, UMIS, and WHMI study units and significantly lower in the Coastal Plain GCP and DLMV study units (Appendix B). Dissolved inorganic nitrogen varied substantially within each study area, but was generally higher in the DLMV and WHMI and lower in the OZRK study units.

EPT richness ranged from 0 to 28 across all study sites, and mean EPT richness varied between 5.8 and 14.5 across study units (Appendix B). Mean EPT richness was significantly lower in the CNBR and DLMV study units (5.8 and 6.3, respectively) and significantly higher in the OZRK, UMIS, and USNK study units $(14.5,11.9$, and 11.4 , respectively; one-way ANOVA, Tukey's contrasts, $P<0.05)$. Using either national or regional tolerance values, there were no large differences between mean tolerances across study units (mean tolerance range 3.7 to 5.9). Mean percentage of intolerant invertebrates based on national tolerance values ranged from $11 \%$ in the CNBR study unit to $47 \%$ in the CCYK study unit. However, when using regional tolerance values, the mean proportion of intolerant invertebrates was more variable between study units ranging from $10 \%$ in the CCYK to $85 \%$ in the WHMI study unit. Noticeably, the percentage of intolerant individuals increased, and the mean tolerance decreased in the CNBR and, especially, WHMI study units when using regional compared to national tolerance values. Established regional tolerance values for the CNBR and WHMI units were notably lower (more intolerant) than national averaged values and especially for taxa that were abundant in the CNBR and WHMI streams, including, for example, genera in the families Baetidae, Elmidae, Chironomidae, and Hydropsychidae.

The proportion of basin cropland was significantly positively correlated with DIN, excess conductivity, suspended organic $\mathrm{C}$, and $\mathrm{TP}$, and significantly negatively correlated with EPT richness, national tolerance (inverted range) and percentage of intolerant taxa; basin cropland was significantly positively correlated with regional tolerance (inverted) and percentage of regionally classified intolerant taxa (Appendix C). The proportion of basin in riparian forested wetland was negatively correlated $(P<0.05)$ with DIN, conductivity, and excess conductivity, TP, and the percentage of intolerant invertebrates (national and regional metrics) and positively correlated with regional mean invertebrates tolerances (inverted range), but not significantly correlated with mean national tolerance or EPT richness. DIN was positively correlated with excess conductivity, suggesting that they might be good candidates for the WQ-d measurement model. Similarly, the indicators of WQ-p measurement model (TP, suspended organic C, and total suspended sediment [TSS]) were all positively correlated $(P<0.05)$.

\section{National SEM model}

In the national-scale analysis, the model fit the data set well, as indicated by all fit statistics (Table 1). The standardized path coefficients (standardized effects) for all measurement model indicators were statistically significant and of relatively similar magnitude, which 
TABLE 1. Structural equation modeling (SEM) fit statistics by region.

\begin{tabular}{lrccccr}
\hline \hline \multicolumn{1}{c}{ Model } & \multicolumn{1}{c}{$\chi^{2}$} & df & $\begin{array}{c}\chi^{2} \\
P \text { value }\end{array}$ & RMSEA & $\begin{array}{c}\text { RMSEA } \\
P \text { value }\end{array}$ & CFI \\
\hline National & 100.178 & 82 & 0.084 & 0.031 & 0.941 & 0.991 \\
Midwest & 102.576 & 94 & 0.256 & 0.028 & 0.855 & 0.994 \\
Western Arid & 110.511 & 98 & 0.183 & 0.047 & 0.518 & 0.979 \\
Coastal Plain & 54.799 & 52 & 0.369 & 0.032 & 0.618 & 0.994 \\
\hline
\end{tabular}

Notes: The $\chi^{2}$ statistics indicate overall fit of the model structure to the structure of the data; good fit shows no significance difference between model and data, $P>0.05$; root mean square error approximation (RMSEA) estimates errors of approximation and thus relates to causal specification of model; good fit shows no significance difference between model and data, $P>0.05$; CFI (Comparative Fit Index) is a type 3 index based on a non-central $\chi^{2}$ distribution, which can handle small sample size and nonnormal data (Tomer and Pugesek 2003); values over 0.9 indicate good fit.

indicated a good-fitting, reliable representation of the latent variables (Table 2; Grace 2003). An exception, relative percentage of riffle habitat did not weigh as strongly as the other indicators of hydraulic habitat, but we chose to leave this variable in the model as it is a very common field assessment metric and was important regionally. There were minor departures from normality for two variables (water surface gradient and relative percentage of riffle habitat); however, the CFI fit index of 0.991 indicated a very good fit of the model structure to the covariance matrix despite these departures from normality. In addition, bootstrapped solutions resulted in the same model structure and fit estimates suggesting our model fit tests were accurate (Shipley 2000).

Overall, our national model suggested that basin cropland had a significant negative impact on aquatic insect community quality ( -0.47 ; Table 3 , Fig. 3a). This negative effect occurred because cropland had strong $(P$ $<0.05$ ) negative total effects (direct plus indirect) on base flow index ( -0.15$)$, hydraulic habitat $(\mathrm{HydH},-0.33$ $[P<0.10]$ ), and coarse substrate availability (CSub, -0.49 ), and at the same time increased (had a positive total effect) on water quality stressors (WQ-d, 0.74; WQ-p, 0.60) and water temperature (0.07). In turn, CSub had significant positive direct effects $(0.48)$ and WQ-d had significant negative direct effects $(-0.22)$ on the invertebrate community quality (ICQ) latent variable, while direct effects of WQ-p were negative $(-0.13)$, but not statistically significant (Table 4).

In contrast to basin cropland, forested wetlands in the riparian buffer had no significant impact on aquatic insect community quality (Table 3 ), although this was largely because water quality improvements associated with riparian forested wetlands $(-0.64$ [WQ-d]; $P<$ 0.05 ) were offset by negative impacts on CSub availability $(-0.29 ; P<0.1)$. To examine the relative strength of the multiple causal pathways affecting ICQ, the total effect was partitioned into the contributing

TABLE 2. Standardized path coefficients for indicators of latent (conceptual) variables from National, Midwest, West, and Coastal Plain models.

\begin{tabular}{|c|c|c|c|c|}
\hline \multirow[b]{2}{*}{ Latent variable } & \multicolumn{4}{|c|}{ Model } \\
\hline & National & Midwest & Western Arid & Coastal Plain \\
\hline Coarse substrate (CSub) & $\begin{array}{l}\text { CGW (0.59) } \\
D_{84}(0.91) \\
\text { NBed }(0.76)\end{array}$ & $\begin{array}{l}\text { CGW (0.59) } \\
D_{84}(0.89) \\
\text { NBed }(0.95)\end{array}$ & $\begin{array}{l}\text { CGW (1.06) } \\
D_{84}(0.83) \\
\text { NBed }(0.89)\end{array}$ & $\begin{array}{l}\text { Wood }(0.94) \\
\text { CanClose }(0.84) \\
\ldots\end{array}$ \\
\hline Hydraulic habitat $(\mathrm{HydH})$ & $\begin{array}{l}\text { RiffRP }(0.42) \\
\text { WSG }(0.79) \\
\text { WCSS }(0.95)\end{array}$ & $\begin{array}{l}\text { Riff }(0.89) \\
\text { WSG }(0.28) \\
\text { WCSS }(0.49)\end{array}$ & $\begin{array}{l}\text { RiffRP }(0.68) \\
\text { WSG }(0.86) \\
\text { WCSS }(0.91)\end{array}$ & $\begin{array}{l}\ldots \\
\text { WSG (1.0) } \\
\ldots\end{array}$ \\
\hline Water quality, dissolved (WQ-d) & $\begin{array}{l}\text { XSCond }(0.71 \\
\text { DIN }(0.78)\end{array}$ & $\begin{array}{l}\text { XSCond }(0.75 \\
\text { DIN }(0.66)\end{array}$ & $\begin{array}{l}\text { XSCond }(0.65 \\
\text { DIN }(0.72)\end{array}$ & $\begin{array}{l}\text { XSCond }(0.86) \\
\text { DIN }(0.85)\end{array}$ \\
\hline Water quality, particulate (WQ-p) & $\begin{array}{l}\text { TP } \dagger(0.65) \\
\text { TSS }(0.76) \\
\text { OrgC }(0.94)\end{array}$ & $\begin{array}{l}\text { TP } \dagger(0.86) \\
\operatorname{TSS}(0.89) \\
\text { OrgC }(0.66)\end{array}$ & $\begin{array}{l}\operatorname{TP}(0.50) \\
\operatorname{TSS}(0.70) \\
\text { OrgC }(0.86)\end{array}$ & $\begin{array}{l}\text { TP }(0.83) \\
\text { TSS }(0.82) \\
\text { OrgC }(0.88)\end{array}$ \\
\hline $\begin{array}{l}\text { Invertebrate community quality } \\
\text { (ICQ) }\end{array}$ & $\begin{array}{l}\text { EPT }(0.65) \\
\text { \%intol }(0.92) \\
\text { Tol }(0.80)\end{array}$ & $\begin{array}{l}\text { EPT }(0.79) \\
\text { \%intol }(0.94) \\
\text { Tol }(0.80)\end{array}$ & $\begin{array}{l}\text { EPT }(0.79) \\
\text { \%intol }(0.77) \\
\text { Tol }(0.87)\end{array}$ & $\begin{array}{l}\text { EPT }(0.79) \\
\text { \%intol }(0.43) \\
\ldots\end{array}$ \\
\hline
\end{tabular}

Notes: Definitions of variables: CGW, percentage of cobble, gravel, and wood; Wood, percentage of wood debris; CanClos, percentage of closed canopy; $D_{84}$, diameter of 84 th percentile particle/hydraulic radius; NBed, percentage of channel not embedded; RiffRP, percentage of riffle/(percentage of run and pool); Riff, percentage of riffle; WSG, water surface gradient; WCSS, water channel shear stress; XSCond, excess conductivity (greater than expected due to natural ionic capacity); DIN, dissolved inorganic nitrogen; TP, total phosphorus; TSS, total suspended sediment; OrgC, suspended organic carbon; EPT, percentage of Ephemeroptera, Plecoptera, and Trichoptera richness; \%intol, percentage of intolerant individuals; Tol, average sample tolerance (inverted). Ellipses indicate that data were not used in that model.

$\dagger$ TP with an upper threshold set at $0.5 \mathrm{mg} / \mathrm{L}$. 
TABLE 3. Estimated model effects: standardized direct, indirect, and total effects of percentage of basin cropland and forested wetland in riparian buffer on endogenous and conceptual variables in SEM model.

\begin{tabular}{|c|c|c|c|c|c|c|}
\hline \multirow[b]{2}{*}{ Model and variables } & \multicolumn{3}{|c|}{ Effects of basin cropland } & \multicolumn{3}{|c|}{ Effects of forested wetland buffer } \\
\hline & Direct & Indirect & Total & Direct & Indirect & Total \\
\hline \multicolumn{7}{|l|}{ National } \\
\hline Base flow index & -0.15 & 0.00 & -0.15 & 0.08 & 0.00 & 0.08 \\
\hline Hydraulic habitat & -0.29 & -0.04 & -0.33 & 0.00 & 0.02 & 0.02 \\
\hline Temperature & 0.00 & 0.07 & 0.07 & 0.00 & -0.04 & -0.04 \\
\hline Coarse substrate & -0.35 & -0.14 & -0.49 & -0.30 & 0.01 & -0.29 \\
\hline Water quality, dissolved & 0.72 & 0.02 & 0.74 & -0.64 & -0.01 & -0.64 \\
\hline Water quality, particulate & 0.54 & 0.06 & 0.60 & 0.03 & 0.00 & 0.04 \\
\hline Invertebrate community quality & 0.00 & -0.47 & -0.47 & 0.00 & -0.01 & -0.01 \\
\hline \multicolumn{7}{|l|}{ Midwest } \\
\hline Base flow index & 0.00 & 0.00 & 0.00 & 0.16 & 0.00 & 0.16 \\
\hline Hydraulic habitat & -0.47 & 0.00 & -0.47 & 0.00 & 0.00 & 0.00 \\
\hline Temperature & 0.00 & 0.00 & 0.00 & 0.00 & -0.06 & -0.06 \\
\hline Coarse substrate & -0.19 & -0.37 & -0.56 & -0.06 & 0.00 & -0.07 \\
\hline Water quality, dissolved & 0.87 & 0.00 & 0.87 & 0.06 & -0.04 & 0.03 \\
\hline Water quality, particulate & 0.29 & 0.39 & 0.68 & -0.04 & -0.01 & -0.06 \\
\hline Invertebrate Community Quality & 0.00 & -0.57 & -0.57 & 0.00 & 0.04 & 0.04 \\
\hline \multicolumn{7}{|l|}{ Western Arid } \\
\hline Base flow index & -0.52 & 0.00 & -0.52 & -0.09 & 0.00 & -0.09 \\
\hline Hydraulic habitat & -0.07 & -0.03 & -0.10 & 0.00 & -0.01 & -0.01 \\
\hline Temperature & 0.00 & 0.18 & 0.18 & 0.00 & 0.03 & 0.03 \\
\hline Coarse substrate & -0.25 & -0.06 & -0.31 & 0.13 & 0.00 & 0.12 \\
\hline Water quality, dissolved & 0.68 & 0.00 & 0.68 & -0.30 & 0.00 & -0.30 \\
\hline Water quality, particulate & 0.27 & -0.11 & 0.17 & -0.29 & -0.03 & -0.32 \\
\hline Invertebrate community quality & 0.00 & -0.59 & -0.59 & 0.00 & 0.18 & 0.18 \\
\hline \multicolumn{7}{|l|}{ Coastal Plain } \\
\hline Base flow index & 0.51 & 0.00 & 0.51 & -0.22 & 0.00 & -0.22 \\
\hline Water surface gradient & 0.19 & 0.00 & 0.19 & 0.00 & 0.00 & 0.00 \\
\hline Temperature & 0.00 & -0.14 & -0.14 & 0.00 & 0.06 & 0.06 \\
\hline Coarse substrate & 0.02 & 0.00 & 0.02 & 0.63 & 0.00 & 0.63 \\
\hline Water quality, dissolved & 0.44 & 0.00 & 0.44 & -0.60 & 0.00 & -0.61 \\
\hline Water quality, particulate & -0.16 & -0.05 & -0.21 & -0.39 & 0.01 & -0.38 \\
\hline Invertebrate community quality & 0.00 & -0.05 & -0.05 & 0.00 & 0.59 & 0.59 \\
\hline
\end{tabular}

Note: Boldface type indicates significance at $P<0.05$; boldface italic type at $P<0.1$.

indirect effects acting through the conceptual variables (Table 5). In the national model, $50 \%$ of the negative effect of basin cropland on ICQ was mediated through CSub availability and 50\% through impacts on water quality (principally via WQ-d, dissolved load). The causal routing for riparian wetland effects was similar, with $49 \%$ transmitted through lowered substrate availability and $49 \%$ through improved water quality effects (again principally due to improved dissolved loads; WQd); although, in this case, the effects are of opposite sign and cancel leading to a small, statistically insignificant total effect.

\section{Regional SEM models}

Based on standard fit indices (Table 1), each of our modified regional models fit their respective data sets well, including the regional measurement model components (Table 2, Fig. 3b-d). Standardized path coefficients for the regional models in some cases differed substantially from the national model reflecting regionally distinct habitat and environmental constraints. Tests of the pooled national measurement model with regional data indicated no changes were necessary in measurement model structure for the WA region and only a minor substitution in the $\mathrm{HydH}$ concept (percentage of riffle habitat vs. the relative percentage of riffle habitat) was needed for the MW region (Table 2). However, in the $\mathrm{CP}$ region substantial revisions of the CSub, HydH, and ICQ measurement models were required to obtain realistic parameterizations. The CP measurement model for $\mathrm{HydH}$ could only be estimated from a single independent variable, water surface gradient, which was one of several indicators used in the national, WA, and MW models. The CP streams had a very different habitat structure with sandy beds, little gravel or cobble, but large amounts of woody debris. Thus, the measurement model for CSub was better represented by the variables percentage of woody debris and the relative percentage of canopy closure (Table 2), a correlate and likely a source of woody debris. Finally, the invertebrate tolerance metric clearly responded much differently than the EPT and percentage of intolerant metrics to stressors in the CP streams so it was removed from the $\mathrm{CP}$ model, leaving two invertebrate metrics as indicators of the invertebrate community conceptual variable (EPT taxa richness and 
percentage of intolerant invertebrates). Kurtosis and skewness for the regional models indicated minor departures from normality, but the CFI indices confirmed good model fit taking into account some nonnormal variable distributions (Table 1).

When analyzed regionally, the total effects of land use/cover on ICQ were highly variable (Table 3 ). Basin cropland had stronger negative effects on ICQ in the MW (total effect $=-0.57, P<0.05)$ and WA $(-0.59, P$ $<0.05)$ regional models than the pooled national model $(-0.47, P<0.05)$, but a much smaller, statistically insignificant effect in the CP regional model $(-0.05)$. In the $\mathrm{CP}$ regional model, percentage of riparian forested wetland buffer had a significant positive effect on the ICQ (0.59). This effect was less strongly positive in the WA regional model $(0.18, P<0.10)$, and statistically insignificant in the MW and pooled national models. Like the national model, the conceptual stressor variable WQ-d had a negative direct effect on ICQ in each of the regional models, but was only significant in the WA model (Table 4). Unlike the national model, WQ-p had a significant effect on ICQ in all of the regional models, negative in the MW and CP models, but positive in the WA model. CSub had a significant positive effect on ICQ in the WA model, but was not significant in either the MW or CP models (Table 4).

The causal pathways from cropland to ICQ differed substantially among the regional models (Table 5). In the MW, cropland effects were transmitted almost entirely via WQ-p ( $85 \%$ of total cropland effects), while in the WA region, they were transmitted via dissolved water quality ( $80 \%$ of total cropland effects). The total effect of cropland on ICQ in the $\mathrm{CP}$ region was small and statistically insignificant, although transmitted primarily through significant effects on WQ-d (-0.15; $60 \%$ ). In contrast to the national model, the coarse substrate pathway was much less important in transmitting cropland impacts in the regional models.

In the regional $\mathrm{CP}$ model, riparian forested wetlands had stronger effects on ICQ than did agriculture. Its effects were positive and transmitted approximately equally through the WQ-d, WQ-p, and CSub concept variables. In the WA region, riparian forested wetland was also an important influence on ICQ, but it acted principally through dissolved water quality (WQ-d). In contrast, in the Midwestern regional analysis, riparian wetland forests had little effect on either invertebrates or on the more proximal physical variables (see Tables 3 and 5).

\section{Discussion}

These analyses clearly support the hypothesis that, across the United States, agricultural land use has strong effects on the ecological structure of local stream ecosystems as reflected in aquatic invertebrate community composition. Our results also indicate that there are significant regional differences in the structure and relative importance of the specific habitat and nutrient pathways through which agriculture affects stream biological integrity. Thus, the national-scale model strongly supports the desirability of national policy to address the water quality and ecological implications of agricultural land use. At the same time, the regional modeling suggests that the implementation of agricultural BMPs and other mitigation strategies likely need to be regionally framed.

\section{National model}

The national SEM provided a useful and robust but "spatially averaged" view of the causal network linking crop cover, riparian cover, and biological integrity. In our conceptual model, we hypothesized that row crop agriculture would have a negative influence on biological integrity via impacts on water quality and structural habitat (Fig. 2). This causal hypothesis was supported in the national SEM (Fig. 3a) and that allowed us to compare the standardized effect strengths of the water quality and habitat pathways. At the national scale, impacts transmitted through habitat and water quality were essentially of equal magnitude. This is consistent with results of many earlier studies that have shown that land use is correlated with changes in both stream channel characteristics (Richards et al. 1996, Wang et al. 1997, Fitzpatrick et al. 2001, Stewart et al. 2001, Goldstein et al. 2007) and water quality (Hunsaker and Levine 1995, Johnson et al.1997, Black et al. 2000). And further, that both basin- and local reach-scale processes were implicated in the causal structure that generated both habitat and water quality impacts (Richards et al. 1997, Lammert and Allan 1999, Zorn et al. 2002, Black et al. 2004, Hutchens et al. 2009, Baker and Wiley 2009).

This USGS NAWQA sampling was originally designed to examine impacts of agricultural nutrient enrichment by sampling streams across a gradient of agricultural practices and under a range of natural environmental conditions (e.g., differing elevation, slope, hydrologic regime, geology). In this analysis, cropland did have significant effects on nutrient and water quality contaminant concentrations in the model. Nutrients were represented by two conceptual variables WQ-d (indicated by DIN and excess conductivity) and WQ-p (indicated by concentrations of TP, TSS, and suspended organic carbon). Together, these water quality concept variables were responsible for transmitting about half of the negative impact of cropland on the invertebrate community in the national data set (Table 5). The direct effects of cropland on the water quality variables were strongest for DIN, suspended organic carbon, and excess conductivity $(0.57,0.56$, and 0.53 , respectively; Appendix D), but were also large and significant for TP and TSS (0.39 and 0.46, respectively). Furthermore, the standardized total effects of cropland on key nutrients and water quality parameters in the national-scale model were much larger than the observed correlations in the data set (and for TSS over seven times larger; see Appendix C). 
a) National SEM

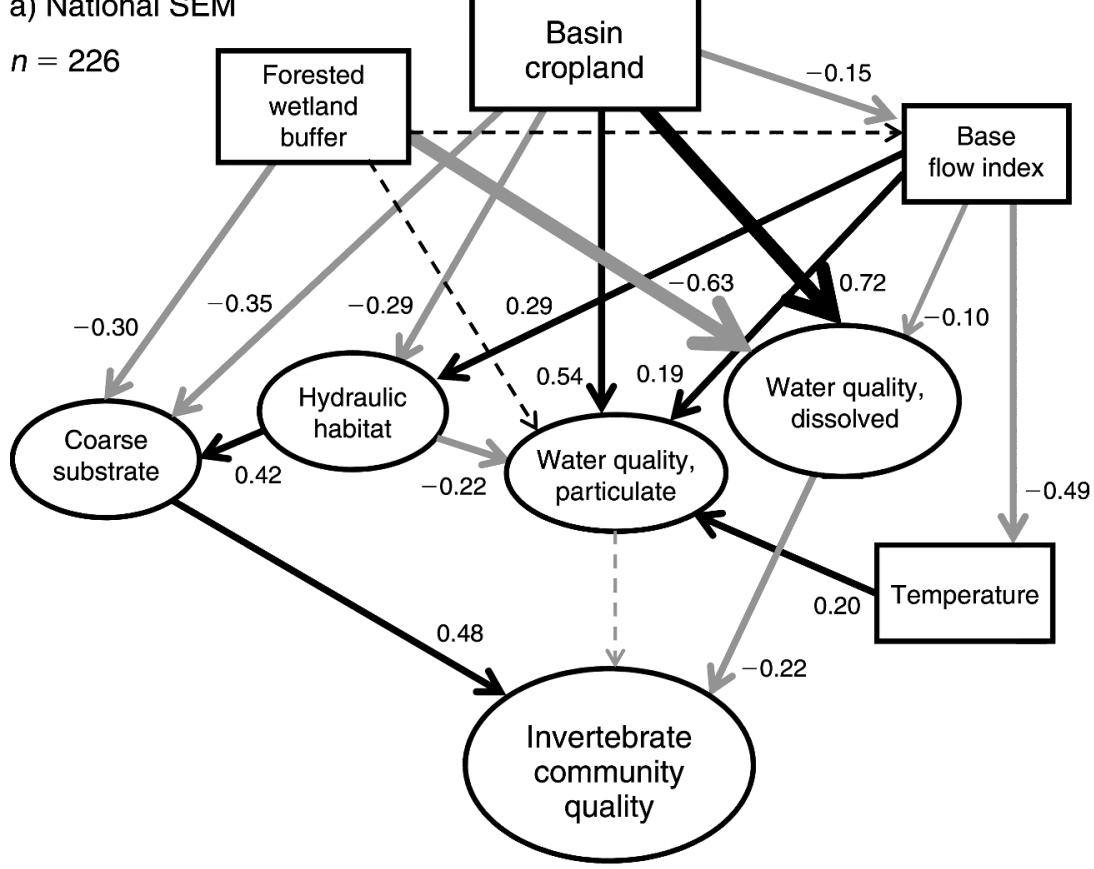

b) Midwest SEM



FIG. 3. National and regional parameterized SEMs showing direct paths between variables: SEM model fitted to (a) national data, (b) Midwest regional data, (c) Western Arid regional data, and (d) Coastal Plain regional data. Black indicates a positive direct effect, gray indicates a negative direct effect, and strongest paths are indicated by thick lines. Insignificant direct effects are shown as dashed lines; correlations were removed for clarity. Sample sizes $(n)$ indicate the number of sites per regional data set used in the SEM analysis. See Table 3 for indirect, total, and insignificant effect magnitudes. 
c) Western Arid SEM



d) Coastal Plain SEM



FIG. 3. Continued. 
TABle 4. Standardized total effects of temperature, base flow index, and model conceptual variables on the invertebrate community quality conceptual variable.

\begin{tabular}{lcccccr}
\hline \hline Region & $\begin{array}{c}\text { Base flow } \\
\text { index }\end{array}$ & $\begin{array}{c}\text { August } \\
\text { water } \\
\text { temperature }\end{array}$ & $\begin{array}{c}\text { Hydraulic } \\
\text { habitat }\end{array}$ & $\begin{array}{c}\text { Coarse } \\
\text { substrate }\end{array}$ & $\begin{array}{c}\text { Water } \\
\text { quality, } \\
\text { dissolved }\end{array}$ & $\begin{array}{c}\text { Water } \\
\text { quality, } \\
\text { particulate }\end{array}$ \\
\hline National & $\mathbf{0 . 0 8}$ & $-\mathbf{0 . 0 3}$ & $\mathbf{0 . 2 3}$ & $\mathbf{0 . 4 8}$ & $-\mathbf{0 . 2 2}$ & -0.13 \\
Midwest & 0.09 & $-\mathbf{0 . 2 2}$ & $\mathbf{0 . 6 1}$ & -0.03 & -0.09 & $-\mathbf{0 . 7 6}$ \\
Western Arid & 0.10 & 0.01 & -0.01 & $\mathbf{0 . 2 8}$ & $-\mathbf{0 . 8 0}$ & $\mathbf{0 . 2 8}$ \\
Coastal Plain & 0.02 & $-\mathbf{0 . 0 5}$ & 0.07 & 0.33 & -0.34 & $\mathbf{- 0 . 4 7}$ \\
\hline
\end{tabular}

Note: Boldface type indicates significance at $P<0.05$; boldface italic type at $P<0.1$.

This suggests that spatial collinearities and spurious correlations may routinely obscure the true magnitude of agricultural impacts on these water quality variables (Appendix D). DIN was an exception in that the direct effect of cropland on DIN was only $85 \%$ of the observed correlation. Path analytical approaches like SEM can tease apart the components of observed correlations in complex causal system since observed correlations are mathematically the sum of all real and spurious (random error and antecedent induced) path effects (Bollen 1989). Here, the effects of cropland on TP, TSS, suspended organic $\mathrm{C}$, and excess conductivity were in fact larger than could be inferred from a simple correlation analysis.

Based on the relative strength of the WQ-d $(-0.22)$ vs. WQ-p (-0.13) effects, dissolved contaminant variables appear to be more widely useful predictors of invertebrate community impairment than particulate water- quality variables in agricultural river systems across the United States (Table 4). In this respect, our results are consistent with earlier reports suggesting conductivity may be a very useful overall indicator of agricultural intensity and its associated chemical runoff (Leland 1995, Munn et al. 2002).

In the national analysis, riparian forested wetlands had significant direct effects on coarse substrate and dissolved water quality (WQ-d), but a surprisingly small effect on particulate water quality (Table 3). Contrary to our expectations, the impacts of riparian forested wetlands on ICQ as mediated through WQ-d (0.14) and CSub $(-0.14)$ effectively cancelled each other out, resulting in an insignificant total effect of riparian forested wetland on the aquatic invertebrate community (Table 5). We had expected that riparian forested wetland would have a positive effect on the stream invertebrate community by

TABLE 5. Relative effects of cropland and riparian buffer forested wetland land use on invertebrate community quality mediated by model latent variables.

\begin{tabular}{|c|c|c|c|c|}
\hline \multirow[b]{2}{*}{ Mediating variable } & \multicolumn{2}{|c|}{ Basin cropland } & \multicolumn{2}{|c|}{ Buffer forested wetland } \\
\hline & Effect & Contribution $(\%)$ & Effect & Contribution (\%) \\
\hline \multicolumn{5}{|l|}{ National model } \\
\hline Total effects & -0.473 & & -0.067 & \\
\hline \multicolumn{5}{|l|}{ Contributing indirect effects } \\
\hline Coarse substrate & -0.236 & 49.9 & -0.142 & 49.2 \\
\hline Water quality, dissolved & -0.162 & 34.3 & 0.141 & 49.1 \\
\hline Water quality, particulate & -0.075 & 15.8 & -0.005 & 1.7 \\
\hline \multicolumn{5}{|l|}{ Midwest model } \\
\hline Total effect & -0.574 & & 0.044 & \\
\hline \multicolumn{5}{|l|}{ Contributing indirect effects } \\
\hline Coarse substrate & 0.015 & 2.5 & 0.002 & 4.2 \\
\hline Water quality, dissolved & -0.074 & 12.2 & -0.002 & 4.2 \\
\hline Water quality, particulate & -0.515 & 85.3 & 0.044 & 91.6 \\
\hline \multicolumn{5}{|l|}{ Western Arid model } \\
\hline Total effect & -0.585 & & 0.183 & \\
\hline \multicolumn{5}{|l|}{ Contributing indirect effects } \\
\hline Coarse substrate & -0.086 & 12.6 & 0.034 & 9.4 \\
\hline Water quality, dissolved & -0.547 & 80.4 & 0.240 & 65.8 \\
\hline Water quality, particulate & 0.047 & 7.0 & -0.090 & 24.8 \\
\hline \multicolumn{5}{|l|}{ Coastal Plain model } \\
\hline Total effect & -0.048 & & 0.595 & \\
\hline \multicolumn{5}{|l|}{ Contributing indirect effects } \\
\hline Coarse substrate & 0.007 & 2.8 & 0.210 & 35.4 \\
\hline Water quality, dissolved & -0.151 & 59.6 & 0.208 & 35.0 \\
\hline Water quality, particulate & 0.096 & 37.6 & 0.176 & 29.6 \\
\hline
\end{tabular}

Note: Percentage of contribution was calculated using the sum of absolute values for contributing effects. 
reducing water quality impacts. Riparian land use, and specifically forested and wetland stream buffers, are frequently important influences on stream water chemistry (Osborne and Wiley 1988, Cooper 1993, Jones et al. 2001, Johnson et al. 2003) and are thought to process nutrients and sediments from upland sources through both floodplain deposition and biological uptake (Gregory et al. 1991, Cooper 1993, Baker et al. 2001). While this turned out to be true, we had failed to anticipate the observed negative effect on ICQ mediated by coarse substrate. This may reflect in part noncausal regional covariation between riparian wetlands and the national CSub measurement model.

The association of riparian forest wetlands with reduced coarse substrate availability was counterintuitive, but likely reflects the fact that forested floodplains typically occur on flat, alluvial surfaces with aggrading fine-grain sediment deposition (Baker and Wiley 2009). This correlation is likely magnified by the fact that the most extensive forested floodplains zones in our data sets occurred in the sandy sites of the Eastern Coastal Plain region (CP). This may have contributed to some spatial, noncausal (spurious) correlation in the national model. However, it is likely riparian wetlands also functionally contribute to a reduction in channel coarse substrate by reducing local flood flows and scour leaving more fines in the channel substratum. On the other hand, they also contribute large amounts of coarse woody debris, which should increase and not decrease coarse substrate availability. Undoubtedly the causal implications are complex. For example, woody debris jams are often associated with pooling during high flows leading to backwater load deposition and retention of finer sediments in the main channel (Naiman and Décamps 1997, Faustini and Jones 2002). We tried to statistically control for noncausal covariance in the national model (and all the models) by allowing free residual (noncausal) correlations between the relevant variables. This apparently strong correlation between reduced coarse substrate availability and riparian swamps turned out to be one of the major weaknesses of the national-scale model, a relationship that all but disappeared in the regional models.

\section{Regional models}

While the national model structure was useful and fit the MW and WA regional data sets with minimal adjustment, it fit the $\mathrm{CP}$ region data set very poorly. Factor loadings were generally similar across the national, MW, and WA models, although they varied somewhat for the hydraulic habitat measurement model. Variation in hydraulic properties isn't surprising given the regional differences in water surface gradient and discharge. However, the $\mathrm{CP}$ regional model required numerous revisions to obtain a good-fitting, ecologically sensible structure. These changes included reducing substrate indicators (to only wood and its' correlates), reducing hydraulic indicators (solely to water surface gradient), and adjusting the indicators of invertebrate community quality (dropping tolerance value scores and leaving only EPT richness and percentage of intolerant invertebrates). Perhaps most surprising of these was the need to reconfigure the ICQ measurement model. In the $\mathrm{CP}$ region, average tolerance value for macroinvertebrates was positively correlated with several stressors and responded in the structural model in the opposite direction of the other ICQ metrics: EPT richness and percentage of intolerant. We concluded the tolerance value-based metric was not a useful indicator of community quality in the $\mathrm{CP}$ region. This is consistent with previous studies that have shown the CP stream invertebrate community is pre-adapted to low flow-low dissolved oxygen (DO) conditions of summer, even in undisturbed sites, making tolerance values difficult to interpret (Davis et al. 2003). Calhoun et al. (2008) also found that low DO, high temperatures, and intermittent flow occurred commonly in CP streams, but reported that higher total nitrogen concentrations were still associated with increased abundances of tolerant species.

Even though we included variables characteristic of specific regions in the national model (e.g., woody debris and forested riparian wetlands) differences between the parameterizations of the regional models suggest that the nation-wide model masked some interesting regional variation in sensitivities of stream ecosystems to agricultural land use. For example, comparing the total effect of basin cropland on ICQ, we found the national model slightly underestimated effect strength for the MW and the WA regions ( -0.47 vs. -0.57 and -0.59 , respectively), but substantially overestimated the effect in the CP region $(-0.05)$ (Table 3). This is not particularly surprising. Geographic differences in data extent/scale will often translate into differences in observed variation, and therefore, in different amounts of variation explained by specific models.

The relative importance of several alternate causal pathways differed across the three modeled regions. In the WA and CP regional models, basin cropland impacts on ICQ were transmitted primarily through dissolved water quality ( -0.55 and -0.15 , respectively; Table 5), but in the MW model through particulate water quality $(-0.52)$, presumably resulting in increased productivity and oxygen stresses on the biological community. In the WA region, the positive effect of WQ-p on ICQ (Table 4) might be explained as a nutrient subsidy in the generally lower nutrient environment of the WA (Appendix B). An important part of the variation in causal structure among the regional and national models was related to differences in the response of specific water quality metrics to land cover composition. Basin cropland had a significant effect on all of water chemistry constituents included in the national and MW models (Appendix D). But, in the WA and CP models, basin cropland had a significant effect on only DIN and excess conductivity. Forested wetlands had a 
significant negative effect on all of the water chemistry parameters in the CP model, significant negative effects on some parameters of the WA and national models, and no statistically significant effects on any of the metrics in the MW model (Appendix D). Thus, the landscape context of a watershed appeared to strongly modulate the strength of various pathways by which agricultural activities and riparian land cover impact stream biotic integrity.

Riparian forested wetlands emerged from our analysis as an important factor mitigating agricultural runoff in the WA, CP, and national models, but not in the MW model. A number of watershed or regional-scale studies relating land use to water chemistry have found positive relationships between natural riparian zones and increased stream water quality (e.g., Johnson et al. 1997, Lowrance et al. 1997, Meador and Goldstein 2003, Riseng et al. 2010). In a national-scale field study, forested riparian buffers were shown to reduce DIN from field runoff by $50-75 \%$ at a majority of sites (Puckett 2004). A riparian forested wetland adjacent to an agricultural field in a coastal plain stream removed or retained $78 \%$ of the nitrate and $66 \%$ of the total phosphorus within the buffer zone (Vellidis et al. 2003). Riparian wetlands are particularly associated with elevated rates of denitrification (Cooper 1990, Gregory et al. 1991) and load dilution, so that streams with extensive riparian wetlands, such as in the $\mathrm{CP}$ region and particularly the GCP streams, have generally lower nutrient and contaminant loads (Bis et al. 2000). These functions of riparian wetlands are reduced if the wetlands have been channelized, reduced in size, or otherwise hydrologically or biologically altered (Puckett and Hughes 2005) and depend on the spatial arrangement of land covers and the surface and groundwater flow paths within a watershed (Puckett 2004, King et al. 2005). In our CP ecosystems, cropland tends to be located on well-drained upland areas separated from streams by undisturbed riparian floodplain habitats, resulting in generally lower pesticide and nutrient concentrations (Frick et al. 1998). In the CP model, positive effects of riparian forested wetland on the invertebrate community far outweighed negative impacts of agriculture, suggesting the importance of intact riparian floodplains and wetlands for maintaining biotic integrity in CP systems (Tables 3 and 5).

Riparian forested wetland had similar positive effects on biotic integrity in the WA region mediated primarily through dissolved components of water quality, but, in contrast to the CP regional model, these effects were small compared to the strong agricultural impacts on dissolved water quality (Tables 3 and 5). The WA region had a high percentage of streams that were channelized or ditched (14-21\% vs. $0-6 \%$ in the other study units), cropland is highly irrigated, and annual precipitation low so that concentrated agricultural contaminants and especially pesticides may be delivered directly to streams without any riparian processing (Clark 1997, Ebbert and Kim 1998, Ebbert and Embrey 2002).

We found no significant effects of riparian forested wetland on either the dissolved or particulate water quality load in the MW region $(P<0.05$; Table 3; Appendix D: Table D1B). Like the WA region, the MW region streams had relatively low proportions of riparian forested wetlands (WA, 0-9.3\%; MW, 0-16.3\%), but did have significantly higher mean proportions of agriculture in the riparian buffer $(47.9 \%$ vs. $30.9 \%$ in the WA region). The strong cropland effects on nutrients and potential contaminants (Table 3; Appendix D: Table D1B) may have resulted in too little variation in water quality to detect small variations in forested riparian wetland, given the smaller amounts of buffering riparian wetland. Watershed-scale studies of land use in riparian buffers have, in general, found strong effects (Johnson et al. 1997, Lowrance et al. 1997, Osborne and Wiley 1988, Baker et al. 2001). However, forested riparian wetland in the Midwest may be exceptionally variable in nutrient retention capacity due to variations in soil drainage, vegetation patterns, and seasonal changes in antecedent moisture. For example, Tompkins et al. (1997) found extensive forested wetlands in the upper Midwest tended to increase nutrient fluxes during wet periods and that low $\mathrm{N}$ and $\mathrm{P}$ concentrations resulted more from dilution than from riparian processing of nutrient loads. It is also possible that the scale of GIS riparian analysis (250-m stream buffers) was inadequate to capture the effects of narrow riparian buffers common in Midwestern streams (Johnson et al. 2003); particularly since Baker et al. (2006) found that using functional "flow-path" riparian metrics provided better explanatory power for riparian nutrient retention than fixed width buffer metrics. Many Midwestern agricultural fields are extensively drained, routing shallow subsurface drainage directly to stream channels (Puckett 2004), and this too may obscure the functional relationship between riparian wetlands and other system stressors.

\section{Model limitations and implications}

As with any model, an SEM is an abstract simplification from a much more complex reality. We used SEM for purposes of model confirmation (not model formulation), which allowed us to test our causal hypotheses about the order and direction of dependency between variables (Grace 2003) and specify how we understand these ecosystems to work and respond to landscape change. However, SEM is not a controlled experiment and cannot prove causation, only support or contradict causal hypotheses. It is particularly useful in landscapescale studies where costs and logistics make direct experimentation difficult at best and would require very long-term studies to generate meaningful data sets. SEM typically requires large data sets $(N>100)$ for better estimation of parameters and increased power in hypothesis testing (Tomer and Pugesek 2003). We tested model fit using a variety of indices, including the 
RMSEA and CFI, which are the least affected by sample size, and all the fit indices indicated a good model fits. In our analyses, adequate SEM sample sizes were achieved for the national and MW models, but sample size for WA and CP models was slightly less than recommended. Increasing the sample size for these regions and further testing these models is clearly desirable.

The objective of our modeling was to examine the indirect pathways by which agriculture affects the biological integrity of streams; particularly with reference to pathways involving nutrient enrichment. In the iterative process of refining the measurement models, the data structure led us to partition the role of nutrients $(\mathrm{N}$ and $\mathrm{P}$ ) between two different latent or conceptual variables. Particulate water quality (WQ-p) seemed functionally related to productivity, oxygen demand, and low oxygen-related metabolic stress. We interpreted dissolved water quality (WQ-d) as more functionally related to toxicity. Each of these latent variables was measured by a different set of reflective indicators correlated with (Chin 1998), but not restricted to nutrient concentrations (Appendix C). Each represented a distinct kind of impact on the insect community and each had varying levels of effect in different regional settings. While we are used to talking about nutrients ( $N$ and $\mathrm{P}$ ) as a single category of stressor, introducing two conceptual variables and causal pathways seemed to capture a more complex understanding of the functional impacts of nutrient enrichment within the SEM. This aspect of our models is somewhat novel and arises from the structure of the data itself and not a priori theory. It should be further refined and tested with additional data on toxic pollutants, temperature, and dissolved oxygen minima to validate the underlying concepts.

The effects of watershed land use have been shown to be related not only to average basin coverage, but also to the distribution and spatial arrangement of cropland, especially in proximity to stream corridors (Osborne and Wiley 1988, Strayer et al. 2003, Baker and Wiley 2009, Riseng et al. 2010). Our national land cover data included variables describing land use composition in a fixed-width buffer, but no data were available that described the arrangement of cropland within a basin or along the specific flow pathways that agricultural runoff might take to a stream corridor (cf. King et al. 2005). Undoubtedly, specific flow path or landscape arrangement data would be useful for both modeling and designing specific regional BMPs.

The SEM developed from the full NAWQA data set provided a useful national-scale summary of the influence of cropland agriculture on the biological integrity of stream ecosystems. It demonstrated that the effects of agriculture include altered physical habitats, degraded water quality, and contributions to local eutrophication across wide ranges of background environmental variation. But the national model also obscured some regionally important variations in how agriculture appeared to effect stream ecosystems. We believe this geographic variability in causal structure is an important result of our analysis. It suggests that with respect to management actions, region-specific approaches may be most appropriate in ameliorating agricultural impacts on biotic integrity. The NAWQA study units provided a good sampling of geographic variation in the continental United States, ranging from the Coastal Plain, through the Midwest plains, to the arid West. However, other important agricultural regions were not represented in this study, including the arid Southwest, the glaciated upper Midwest, and the Northeastern and the Appalachian highlands. These regions have substantively different climate, physiography, and agricultural practices. Given our observation that regionally specific models were needed to capture regional variability, we expect more detailed regional studies will be pivotal in developing mitigation strategies and more ecologically benign agricultural practices both in the United States and globally.

\section{ACKNOWLEDGMenTS}

We thank the many USGS scientists and technicians who were involved in the collection, assembly, and analysis of these data as part of this U.S. Geological Survey NAWQA study. Our special thanks also to I. Waite, R. J. Stevenson, R. Pillsbury, and M. Baker for their input during the preparation of this paper. We appreciate several reviewers for constructive comments that much improved the manuscript. The work reported here was supported by a cooperative agreement between the U.S. Geological Survey and the School of Natural Resources and Environment, University of Michigan (M. J. Wiley, principal investigator; 07WRAG0008).

\section{Literature Cited}

Alexander, R. B., and R. A. Smith. 2006. Trends in the nutrient enrichment of U.S. rivers during the late 20th century and their relation to changes in probable stream trophic conditions. Limnology and Oceanography 51:639-654.

Alexander, R. B., R. A. Smith, and G. E. Schwarz. 2000. Effect of stream channel size on the delivery of nitrogen to the Gulf of Mexico. Nature 403:758-761.

Allan, J. D., and L. B. Johnson. 1997. Catchment scale analysis of aquatic ecosystems. Freshwater Biology 37:107-111.

Andersen, J. R., E. E. Hardy, J. T. Roach, and R. E. Witmer. 2001. A land use and land cover classification system for use with remote sensor data. Professional Paper 964. USGS, Washington, D.C., USA.

Arbuckle, J. L., and W. Wothke. 1999. Amos 4.0 user's guide. SmallWater Corporation, Chicago, Illinois, USA.

Baker, M. E., D. E. Weller, and T. E. Jordan. 2006. Improved methods for quantifying potential nutrient interception by riparian buffers. Landscape Ecology 21:1327-1345.

Baker, M. E., and M. J. Wiley. 2009. Multiscale control of flooding and riparian-forest composition in Lower Michigan, USA. Ecology 90:145-159.

Baker, M. E., M. J. Wiley, and P. W. Seelbach. 2001. GISbased hydrologic modeling of riparian areas: implications for stream water quality. Journal of the Water Resources Association 37:1615-1628.

Barbour, M. T., J. Gerritsen, B. D. Snyder, and J. B. Stribling. 1999. Rapid bioassessment protocols for use in streams and wadeable rivers: periphyton, benthic macroinvertebrates, and fish. EPA 841-B-99-002. U.S. Environmental Protection Agency, Washington, D.C., USA.

Bis, B., A. Zdanowicz, and M. Zalewski. 2000. Effects of catchment properties on hydrochemistry, habitat complexity 
and invertebrate community structure in a lowland river. Hydrobiologia 422/423:369-387.

Black, R. W., A. L. Haggland, and F. D. Voss. 2000. Predicting the probability of detecting organochlorine pesticides and polychlorinated biphenyls in stream systems on the basis of land use in the Pacific Northwest, USA. Environmental Toxicology and Chemistry 19:1044-1054.

Black, R. W., M. D. Munn, and R. W. Plotnikoff. 2004. Using macroinvertebrates to identify biota-land cover optima at multiple scales in the Pacific Northwest, USA. Journal of the North American Benthological Society 23:340-362.

Bollen, K. A. 1989. Structural equations with latent variables. Wiley, New York, New York, USA.

Calhoun, D. L., M. B. Gregory, and H. S. Weyers. 2008. Algal and invertebrate community composition along agricultural gradients: a comparative study from two regions of the Eastern United States. Scientific Investigations Report 20085046. USGS, Reston, Virginia, USA.

Chin, W. W. 1998. Issues and opinion on structure equation modeling. MIS Quarterly Archives 22:1-8.

Clark, G. M. 1997. Assessment of nutrients, suspended sediment and pesticides in surface water of the Upper Snake River Basin, Idaho and western Wyoming, water years 199195. Water-Resources Investigation Report 97-4020. USGS, Reston, Virginia, USA.

Cooper, A. B. 1990. Nitrate depletion in the riparian zone and stream channel of a small headwater catchment. Hydrobiologia 202:13-26.

Cooper, C. M. 1993. Biological effects of agriculturally derived surface water pollutants on aquatic systems: a review. Journal of Environmental Quality 22:402-408.

Cuffney, T. F. 2003. User's manual for the National Water Quality Assessment Program Invertebrate Data Analysis System (IDAS) software: Version 3. Open File Report 03172. USGS, Raleigh, North Carolina, USA.

Cummins, K. W. 1962. An evaluation of some techniques for the collection and analysis of benthic samples with special emphasis on lotic waters. American Midland Naturalist 67:477-504.

Cushing, C. E., and J. D. Allan. 2001. Streams: their ecology and life. Academic Press, San Diego, California, USA.

Davis, S., S. W. Golladay, G. Vellidis, and C. M. Pringle. 2003. Macroinvertebrate biomonitoring in intermittent coastal plains streams impacted by animal agriculture. Journal of Environmental Quality 32:1036-1043.

Diaz, R. J. 2001. Overview of hypoxia around the world. Journal of Environmental Quality 30:275-281.

Dodds, W. K., and R. M. Oakes. 2006. Controls on nutrients across a prairie stream watershed: land use and riparian cover effects. Journal of Environmental Management 37:634-646.

Ebbert, J. C., and S. S. Embrey. 2002. Pesticides in surface water of the Yakima River Basin, Washington, 1999-2000: their occurrence and an assessment of factors affecting concentrations and loads. Water-Resources Investigation Report 01-4211. USGS, Portland, Oregon, USA.

Ebbert, J. C., and M. H. Kim. 1998. Relation between irrigation method, sediment yields, and losses of pesticides and nitrogen. Journal of Environmental Quality 27:372-380.

ESRI [Environmental Systems Research Institute]. 1997. ArcInfo Workstation. ESRI, Redlands, California, USA

Falkenmark, M., and J. Rockström. 2006. The new Blue and Green water paradigm: breaking new ground for water resource planning and management. Journal of Water Resources Planning and Management 132:129-132.

Faustini, J. M., and J. A. Jones. 2002. Influence of large woody debris on channel morphology and dynamics in steep, boulder-rich mountain streams, western Cascades, Oregon. Geomorphology 51:187-205.

Fishman, M. J. 1993. Methods of analysis by the U.S. Geological Survey National Water Quality Laboratory; determination of inorganic and organic constituents in water and fluvial sediments. Open File Report 93-125. USGS, Denver, Colorado, USA.

Fitzpatrick, F. A., B. C. Scudder, B. N. Lenz, and D. J. Sullivan. 2001. Effects of multi-scale environmental characteristics on agricultural stream biota in eastern Wisconsin. Water Resources Research 37:1489-1507.

Fitzpatrick, F. A., I. R. Waite, P. J. D'Arconte, M. R. Meador, M. A. Maupin, and M. E. Girtz. 1998. Revised methods for characterizing stream habitat in the National Water Quality Assessment Program. Water-Resources Investigation Report 98-4052. USGS, Raleigh, North Carolina, USA.

Frick, E. A., D. J. Hippe, G. R. Buell, C. A. Couch, E. H. Hopkins, D. J. Wangsness, and J. W. Garrett. 1998. Water quality of the Apalachicola-Chattahoochee-Flint River Basin, Georgia, Alabama, and Florida, 1992-1995. Circular 1164. USGS, Reston, Virginia, USA.

Frissell, C. A., and D. Bayles. 1996. Ecosystem management and the conservation of aquatic biodiversity and ecological integrity. Water Resources Bulletin 32:229-240.

Fuhrer, G. J., R. J. Gilliom, P. A. Hamilton, J. L. Morace, L. H. Nowell, J. F. Rinella, J. D. Stoner, and D. A. Wentz. 1999. The quality of our nation's waters: nutrients and pesticides. Circular 1225. USGS, Reston, Virginia, USA.

Gilliom, R. J., J. E. Barbash, C. G. Crawford, P. A. Hamilton, J. D. Martin, N. Nakagaki, L. H. Nowell, J. C. Scott, P. E. Stackelberg, G. P. Thelin, and D. M. Wolock. 2006. The quality of our nation's waters: pesticides in the nation's streams and ground water, 1992-2001. Circular 1291. USGS, Reston, Virginia, USA.

Goldstein, R. M., D. M. Carlisle, M. R. Meador, and T. M. Short. 2007. Can basin land use effects on physical characteristics of streams be determined at broad geographic scales? Environmental Monitoring and Assessment 130:495-510.

Gordon, N. D., T. A. McMahon, and B. L. Finlayson. 1995. Stream hydrology: an introduction for ecologists. Wiley, New York, New York, USA.

Grace, J. B. 2003. Examining the relationship between environmental variables and ordination axes using latent variables and structural equation modeling. Pages 171-193 in B. H. Pugesek, A. Tomer, and A. vonEye, editors. Structural equation modeling: application in ecological and evolutionary biology. Cambridge University Press, Cambridge, UK.

Gregory, S. V., F. J. Swanson, W. A. McKee, and K. W. Cummins. 1991. An ecosystem perspective of riparian zones. BioScience 41:540-551.

Heatherly, T., M. R. Whiles, T. V. Royer, and M. B. David. 2007. Relationships between water quality, habitat quality, and macroinvertebrate assemblages in Illinois streams. Journal of Environmental Quality 36:1653-1660.

Hershberger, S. L., G. A. Marcoulides, and M. M. Parramore. 2003. Structural equation modeling: an introduction. Pages 3-41 in B. H. Pugesek, A. Tomer, and A. vonEye, editors. Structural equation modeling: application in ecological and evolutionary biology. Cambridge University Press, Cambridge, UK.

Hilsenhoff, W. L. 1988. Rapid field assessment of organic pollution with a family-level biotic index. Journal of the North American Benthological Society 7:65-68.

Hunsaker, C. T., and D. A. Levine. 1995. Hierarchical approaches to the study of water quality in rivers. BioScience 45:193-203.

Hutchens, J. J., J. A. Schuldt, C. Richards, L. B. Johnson, G. E. Host, and D. H. Breneman. 2009. Multi-scale mechanistic indictors of Midwestern USA stream macroinvertebrates. Ecological Indicators 9:1138-1150.

Johnson, L. B., C. Richards, G. E. Host, and J. W. Arthur. 1997. Landscape influences on water chemistry in Midwestern stream ecosystems. Freshwater Biology 37:193-208.

Johnson, L. B., C. Richards, G. E. Host, and J. W. Arthur. 2003. Landscape influences on water chemistry in Midwestern stream ecosystems. Freshwater Biology 37:163-175. 
Johnson, M. R., and R. B. Zelt. 2005. Protocols for mapping and characterizing land use/land cover in riparian zones. Open-File Report 2005-1302. USGS, Reston, Virginia, USA.

Jones, K. B., A. C. Neale, M. S. Nash, R. D. Van Remortel, J. D. Wickham, K. H. Ritters, and R. V. O'Neill. 2001. Predicting nutrient and sediment loading to streams from landscape metrics: a multiple watershed study from the United States Mid-Atlantic Region. Landscape Ecology 16:301-312.

Karr, J. R., and E. W. Chu. 1999. Restoring life in running waters: better biological monitoring. Island Press, Washington, D.C., USA.

King, R. S., M. E. Baker, D. F. Whigham, D. E. Weller, T. E. Jordan, P. F. Kazyak, and M. K. Hurd. 2005. Spatial considerations for linking watershed land cover to ecological indicators in streams. Ecological Applications 15:137-153.

Lammert, M., and J. D. Allan. 1999. Assessing biotic integrity of streams: effects of scale in measuring the influence of land use/cover and habitat structure on fish and macroinvertebrates. Journal of Environmental Management 23:257-270.

Leland, H. V. 1995. Distribution of phytobenthos in the Yakima River basin, Washington, in relation to geology, land use, and other environmental factors. Canadian Journal of Fisheries and Aquatic Sciences 52:1108-1129.

Lowrance, R., et al. 1997. Water quality functions of riparian forest buffers in Chesapeake Bay watersheds. Journal of Environmental Management 21:687-712.

Malmqvist, B., and S. Rundle. 2002. Threats to the running water ecosystems of the world. Environmental Conservation 29:134-153.

Maxted, J. R., M. T. Barbour, J. Gerritsen, V. Poretti, N. Primrose, A. Silvia, D. Penrose, and R. Renfrow. 2000. Assessment framework for mid-Atlantic coastal plain streams using benthic macroinvertebrates. Journal of the North American Benthological Society 19:128-144.

Meador, M. R., and R. M. Goldstein. 2003. Assessing water quality at large geographic scales: relations among land use, water physiochemistry, riparian condition, and fish community structure. Journal of Environmental Management 31:504-517.

Moulton, S. R., J. Kennen, R. M. Goldstein, and J. A. Hambrook. 2002. Revised protocols for sampling algal, invertebrate, and fish communities as part of the National Water-Quality Assessment Program. Open-File Report 02150. USGS, Reston, Virginia, USA.

Mueller, D. K., and N. E. Spahr. 2006. Nutrients in streams and rivers across the nation: 1992-2001. Scientific Investigations Report 2006-5107. USGS, Reston, Virginia, USA.

Munn, M. D., R. W. Black, and S. J. Gruber. 2002. Response of benthic algae to environmental gradients in an agriculturally dominated landscape. Journal of the North American Benthological Society 21:221-237.

Munn, M. D., I. R. Waite, and D. P. Larsen. 2009. The relative influence of geographic location and reach-scale habitat on benthic invertebrate assemblages in six ecoregions. Environmental Monitoring and Assessment 154:1-14.

Naiman, R. J., and H. Décamps. 1997. The ecology of interfaces: riparian zones. Annual Review of Ecology, Evolution, and Systematics 28:621-58.

Osborne, L. L., and M. J. Wiley. 1988. Empirical relationship between land use/cover and stream water quality in an agricultural watershed. Journal of Environmental Management 26:9-27.

Patton, C. J., and J. R. Kryskalla. 2003. Methods of analysis by the U.S. Geological Survey National Water Quality Laboratory: evaluation of alkaline persulfate digestion as an alternative to Kjeldahl digestion for determination of total and dissolved nitrogen and phosphorus in water. WaterResources Investigations Report 2003-4174. USGS, Denver, Colorado, USA.
Puckett, L. J. 2004. Hydrogeologic controls on the transport and fate of nitrate in groundwater beneath riparian buffer zones: results from thirteen studies across the United States. Water Science and Technology 49:47-53.

Puckett, L. J., and W. B. Hughes. 2005. Transport and fate of nitrate and pesticides: hydrology and riparian zone processes. Journal of Environmental Quality 34:2278-2292.

Pugesek, B. H., and J. B. Grace. 1998. On the utility of path modeling for ecological and evolutionary studies. Functional Ecology 12:853-856.

Rabalais, N. N., R. E. Turner, and D. Scavia. 2002. Beyond science into policy: Gulf of Mexico hypoxia and the Mississippi River. BioScience 52:129-142.

Richards, C., R. J. Haro, L. B. Johnson, and G. E. Host. 1997. Catchment and reach-scale properties as indicators of macroinvertebrate species traits. Freshwater Biology 37:219-230.

Richards, C., L. B. Johnson, and G. E. Host. 1996. Landscapescale influences on stream habitat and biota. Canadian Journal of Fisheries and Aquatic Sciences 53:295-311.

Riseng, C. M., M. J. Wiley, P. W. Seelbach, and R. J. Stevenson. 2010. An ecological assessment of Great Lakes tributaries in the Michigan Peninsulas. Journal of Great Lakes Research 36:505-519.

Riseng, C. M., M. J. Wiley, and R. J. Stevenson. 2004. Hydrologic disturbance and nutrient effects on benthic community structure in Midwestern US streams: a covariance structure analysis. Journal of North American Benthological Society 23:309-326.

Riseng, C. M., M. J. Wiley, R. J. Stevenson, T. G. Zorn, and P. W. Seelbach. 2006. Comparison of coarse and fine scale sampling on statistical modeling of landscape effects and assessment of fish assemblages of the Muskegon River, Michigan. American Fisheries Society Symposium 48:555575.

Ruddy, B. C., D. L. Lorenz, and D. K. Mueller. 2006. Countylevel estimates of nutrient inputs to the land surface of the conterminous United States, 1982-2001. Scientific Investigations Report 2006-5012. USGS, Reston, Virginia, USA.

Scanlon, B. R., I. Jolly, M. Sophocleous, and L. Zhang. 2007. Global impacts of conversion from natural to agricultural ecosystems on water resources: quantity versus quality. Water Resources Research 43:W03437. [doi: 10.1029/ 2006WR005486]

Seelbach, P. W., and M. J. Wiley. 2005. Landscape-based modeling as the basis for a prototype information system for ecological assessment of Lake Michigan tributaries. Pages 559-581 in T Edsall and M. Munawar, editors. State of Lake Michigan: ecology, health, and management. Ecovision World Monograph Series. Aquatic Ecosystem Health and Management Society, New Delhi, India.

Sharpley, A. N., P. J. A. Kleinman, P. Jordan, L. Bergström, and A. L. Allen. 2008. Evaluating the success of phosphorus management from field to watershed. Journal of Environmental Quality 38:1981-1988.

Shelton, L. R. 1994. Field guide for collecting and processing stream-water samples for the National Water-Quality Assessment Program. Open-File Report 94-455. USGS, Sacramento, California, USA.

Shipley, B. 2000. Cause and correlation in biology: a user's guide to path analysis, structural equations and causal inference. Cambridge University Press, Cambridge, UK.

Simley, J. D., and W. J. Carswell, Jr. 2009. The national map: hydrography. Fact Sheet 2009-3054. USGS, Denver, Colorado, USA.

Smith, V. H. 2002. Eutrophication of freshwater and coastal marine ecosystems: a global problem. Environmental Science and Pollution Research 10:126-139.

Snyder, C. D., J. A. Young, R. Villella, and D. P. Lemarié. 2003. Influences of upland and riparian land use patterns on stream biotic integrity. Landscape Ecology 18:647-664. 
SPSS. 2009. PASW Statistics 18. SPSS, Chicago, Illinois, USA Steiner, J. L., R. I. Starks, A. Daniel, J. D. Garbrecht, D. Moriasi, S. McIntyre, and S. Chen. 2008. Environmental effects of agricultural conservation: a framework for research in two watersheds in Oklahoma's Upper Washita River Basin. Journal of Soil and Water Conservation 63:443-452.

Stevenson, R. J., S. Rier, C. M. Riseng, C. M. Schultz, and M. J. Wiley. 2006. Comparing effects of nutrients on algal biomass in streams in two regions with different disturbance regimes and with application for developing nutrient criteria. Hydrobiologia 556:149-165.

Stewart, J. S., L. Wang, J. Lyons, J. A. Horwatich, and R. Bannerman. 2001. Influences of watershed, riparian-corridor, and reach-scale characteristics on aquatic biota in agricultural watersheds. Water Resources Research 37:1475-1487.

Strayer, D. L., R. E. Beighley, L. C. Thompson, S. Brooks, C. Nilsson, G. Pinay, and R. J. Naiman. 2003. Effects of land cover on stream ecosystems: roles of empirical models and scaling issues. Ecosystems 6:407-423.

Tomer, A, and B. H. Pugesek. 2003. Guidelines for the implementation and publication of structural equation models. Pages 125-140 in B. H. Pugesek, A. Tomer, and A. von Eye, editors. Structural equation modeling: applications in ecological and evolutionary biology. Cambridge University Press, Cambridge, UK.

Tompkins, T., W. Whipps, L. Manor, M. J. Wiley, C. Radcliffe, and D. Majewski. 1997. Wetland effects on hydrological and water quality characteristics of a mid-Michigan river system. Pages 273-385 in C. Trettin, M. Jurgensen, D. Grigal, and M. Gale, editors. Northern forested wetlands: ecology and management. CRC Press, Boca Raton, Florida, USA.

U.S. EPA [U.S. Environmental Protection Agency]. 2000. Nutrient criteria technical guidance manual-rivers and streams. Office of Water, EPA 841-R-02-001. U.S. EPA, Washington, D.C., USA.

U.S. EPA [U.S. Environmental Protection Agency]. 2004. National water quality inventory: Report to Congress, 2004 reporting cycle. Office of Water. EPA-841-R-08-00. U.S. EPA, Washington, D.C., USA.

USGS [U.S. Geological Survey]. 1999. The quality of our nation's waters: nutrients and pesticides. Circular 1225. USGS, Reston, Virginia, USA.

Velleman, P. F. 1997. Data Desk: statistics guide. Version 6.1. Data Description, Ithaca, New York, USA.

Vellidis, G., R. Lowrance, P. Gay, and R. K. Hubbard. 2003. Nutrient transport in a restored riparian wetland. Journal of Environmental Quality 32:711-726.
Verhoeven, J. T. A., B. Arheimer, C. Yin, and M. M. Hefting. 2006. Regional and global concerns over wetlands and water quality. Trends in Ecology and Evolution 21:96-203.

Vogelmann, J. E., S. M. Howard, L. Yang, C. R. Larson, B. K. Wylie, and N. Van Driel. 2001. Completion of the 1990's national land cover dataset for the conterminous United States from Landsat Thematic Mapper data and ancillary data sources. Photogrammetric Engineering and Remote Sensing 67:650-662.

Waite, I. R., A. T. Herlihy, D. P. Larsen, N. S. Urquhart, and D. J. Klemm. 2004. The effects of macroinvertebrate taxonomic resolution in large landscape bioassessments: an example from the Mid-Atlantic Highlands, U.S.A. Freshwater Biology 49:474-489.

Wang, L., T. Brenden, P. W. Seelbach, A. Cooper, J. D. Allan, R. D. Clark, Jr., and M. J. Wiley. 2008. Landscape based identification of human disturbance gradients and reference conditions for Michigan streams. Environmental Monitoring and Assessment 141:1-17.

Wang, L., J. Lyons, P. Kanehl, and R. Gatti. 1997. Influences of watershed land use on habitat quality and biotic integrity in Wisconsin streams. Fisheries 22:6-12.

Wang, L., D. M. Robertson, and P. J. Garrison. 2007. Linkages between nutrients and assemblages of macroinvertebrates and fish in wadeable streams: implication to nutrient criteria development. Journal of Environmental Management 39:194-212.

Whiles, M. R., B. L. Brock, A. C. Franzen, and S. C. Dinsmore. 2000. Stream invertebrate communities, water quality, and land-use patterns in an agricultural drainage basin of northeastern Nebraska, USA. Journal of Environmental Manangement 26:563-576.

Wiley, M. J., P. W. Seelbach, K. Wehrly, and J. S. Martin. 2002. Regional ecological normalization using linear models: a meta-method for scaling stream assessment indicators. Pages 201-233 in T. P. Simon, editor. Biological response signatures: indicator patterns using aquatic communities. CRC Press, Boca Raton, Florida, USA.

Wolock, D. M. 2003. Base-flow index grid for the United States. Open-File Report 03-263. USGS, Reston, Virginia, USA.

Zorn, T. G., P. W. Seelbach, and M. J. Wiley. 2002. Distributions of stream fishes and their relationship to stream size and hydrology in Michigan's Lower Peninsula. Transactions of the American Fisheries Society 131:70-95.

\section{APPENDIX A}

Study unit features: summary of dominant study unit features. Mean values and ranges are shown for annual precipitation, air temperatures, and study site basin area (Ecological Archives A021-139-A1).

\section{APPENDIX B}

Site variable means (mean and standard deviation of environmental, physical habitat, water chemistry, and invertebrate variables for sampled sites) (Ecological Archives A021-139-A2).

\section{APPENDIX C}

Pearson correlation matrix with two-tailed significance test (Ecological Archives A021-139-A3).

\section{APPENDIX D}

Total standardized effects of basin cropland and riparian forested wetland on nutrients in the national and regional SEMs (Ecological Archives A021-139-A4). 